\title{
Children of Imprisoned Parents in Scandinavia: Their Problems, Treatment and the Role of Scandinavian Penal Culture
}

\author{
Peter Scharff Smith
}

\begin{abstract}
In some ways, the issue of prisoner's children seems to be one of the major Gordian knots facing the practice of punishment and imprisonment today. How can we punish parents committing serious crimes and still respect the situation and rights of their children? This issue has begun to attract attention during recent years, after having been more or less neglected throughout most of the history of the prison. Empirical research on, reports on, and advocacy for children of imprisoned parents have, for example, been produced in Scandinavia during recent years by researchers, NGOs and children's Ombudsmen. Based on this research as well as on personal observations and new empirical data, I will in this article take a closer look at the situation of prisoners' children in Denmark, Sweden and Norway. I will look into how many children who experience parental imprisonment and the problems they often face-especially in Denmark where most of the Scandinavian empirical research has been done. I will also describe some of the recent initiatives, reforms and good practice, which has been introduced, or is currently in the process of being introduced, in the Scandinavian countries. One example is the children's officers, that is, prison officers with special training who are responsible for enhancing the possibilities for improved contact between children and their imprisoned parents. Finally, I will discuss to what degree specific Scandinavian penal practices might influence the conditions experienced by prisoners' children. As I will show, there are examples of Scandinavian practices, which can both enhance and worsen the situation of prisoners' children. ${ }^{1}$
\end{abstract}

\section{INTRODUCTION}

Historians usually agree that prisons have existed since the 16th century as institutions specifically constructed to incarcerate a significant number of people for prolonged periods of time. ${ }^{2}$ In much of this time, and especially during the last approximately 200 years, the effects of imprisonment have been discussed intensively. The many discussions on the effects of

1 The perspective in this article will mainly be sociological and criminological. For a broader analysis which, for example, includes a legal human rights perspective, see Peter Scharff Smith, When the Innocent are Punished. The Children of Imprisoned Parents (Palgrave, 2014).

2 See, eg, Peter Scharff Smith, Moralske Hospitaler. Det Moderne Fongselsvcesens Gennembrud 1770-1870 (Forum, 2003) 25. 
prisons and punishment have typically focused on either the effects on the individual prisoner (individual deterrence and rehabilitation of prisoners) or the possible preventive effect on society at large (general deterrence). The question of how the use of imprisonment has otherwise affected society, and, for example, the relatives and children of those imprisoned, has by comparison gained very sparse attention during the last two centuries. ${ }^{3}$ As late as 2005, Alison Liebling and Shadd Maruna concluded in a volume on The Effects of Imprisonment that:

there is little research emphasis on the effects of imprisonment on prisoner's families [and] the impact of imprisonment upon the children of prisoners has been slow to appear in the literature on the effects of imprisonment. ${ }^{4}$

The last 10-15 years has, however, witnessed a gradually rising interest in, and research on, the broader societal effects of the use of imprisonment. The background of this interest is unfortunately - at least partly - the alarming rise in prison populations that many nations have witnessed. This trend, of course, also means that an increasing number of children experience parental imprisonment and that families and relationships are challenged and broken up on a massive scale. While the Scandinavian countries have low rates of imprisonment compared to most other parts of the world, penal populism has nevertheless appeared also in Norway, Sweden and Denmark. ${ }^{5}$ In all three countries, the mass of sentences of imprisonment (the number of sentences multiplied by the length) rose from 2006 to 2010 and in Norway the prison population went up 12\% during the same period, although it fell in Sweden. ${ }^{6}$ In both Norway and Sweden, however, the prison population has risen significantly since the early 1990 s. ${ }^{7}$ Currently, the prison population is witnessing an interesting and quite sudden decline in Sweden and in October 2013 it was back to the 2001 level (but still higher than the early 1990s). ${ }^{8}$ In Denmark, the

3 Robert Sampson, for example, states: 'It is not much of an oversimplification to say that criminologists once focused almost exclusively on the deterrent and incapacitation effects of imprisonment ... whereas in the last decade the tide has turned to a widespread focus on the negative or "criminogenic" effects of imprisonment' in 'The Incarceration Ledger: Toward a New Era in Assessing Societal Consequences' (2011) 10(3) Criminology \& Public Policy 819.

4 Alison Liebling and Shadd Maruna 'Introduction: The Effects of Imprisonment Revisited' in A Liebling and S Maruna (ed), The Effects of Imprisonment (Willan, 2005) 16.

5 See, eg, Vagn Greve 'Retten og Samfundet' in Nordisk Tidsskrift for Kriminalvidenskab (2011) No 1; Hans Jørgen Engbo and Peter Scharff Smith, Fongsler og Menneskerettigheder (Jurist og Økonomforbundets Forlag, 2012); Laila Freivalds, 'Politikerna och Kriminalpolitiken' (2012) 2 Nordisk Tidsskrift for Kriminalvidenskab 123-127.

6 Susanne Hildebrandt (ed), Nordisk Statistik for Kriminalforsorgen i Danmark, Finland, Island, Norge og Sverige 2006-2010 (Direktoratet for Kriminalforsorgen, 2014) $16 \mathrm{ff}$.

7 See data supplied on the ICPS world prison brief $<$ http://www.prisonstudies.org/ info/worldbrief/>.(5 September 2013).

8 See data supplied on the ICPS world prison brief<http://www.prisonstudies.org/ info/worldbrief/> (17 June 2014). 
impact of penal populism has caused a rise in the prison population, which has gone up by $23 \%$ from 2001 to 2012, as a result of, among other things, legislation introducing longer sentences, while a slight decline has set in during $2014 .^{9}$

\section{PRison And Society - AND the Legacy of The Modern Penitentiary}

While the history of the prison - as an institution used for punishment goes back to the 16 th century it was not until the late 18 th century and especially the 19th century that imprisonment came to play the central role as a state tool for punishment and in the fight against crime as it still does today. Accordingly it was in the 19th century that prisons were constructed on a large scale throughout the Western world and thereby both in an ideological and physical sense came to shape the foundation for our current prison practices.

The modern penitentiary was based on an ideology of rehabilitation through isolation, which was expressed in the American Auburn and Pennsylvania prison models of the 1820s. A natural, but often more or less ignored or simply overlooked, consequence of the breakthrough of the modern penitentiary and its ideology of rehabilitation through isolation, was that almost all contact between the prisoner and his or her family was cut off. In Denmark, for example, prisoners in a modern penitentiary of the 1860's were not allowed any visits at all during the first three months of their incarceration and were allowed to write one letter in that period. If prisoners behaved well, they were thereafter allowed to write a letter and receive a visit every second month. At a later stage, at the earliest after 21 months of imprisonment, one visit and correspondence could be allowed on a monthly basis. ${ }^{10}$

Unfortunately the 19th century system of solitary confinement, and the employment of prison regimes with high degrees of isolation, was very persistent, not least in Scandinavia. The vision of rehabilitation through isolation was expressed most radically in the Pennsylvania model prisons, which became extremely popular in Scandinavia and other European countries. While the use of large scale Pennsylvania model solitary confinement was abandoned relatively quickly in several states of the United States, around the middle of the 19th century, it continued in several places in Europe. In Holland, Belgium, Sweden, Norway, and Denmark, the model continued well into the 20th century. ${ }^{11}$ As late as 1918, in a Danish Pennsylvania model prison, each prisoner was only allowed a 15-minute visit every third month and correspondence was

$9 \quad$ Kriminalforsorgens statistik 2010: 21 and Kriminalforsorgens statistik 2012:14.

10 Smith, above n 2, 192.

11 Peter Scharff Smith, 'The Effects of Solitary Confinement on Prison Inmates: A Brief History and Review of the Literature' in M Tonry (ed), Crime and Justice, Vol 34 (Chicago University Press, 2006) 467. 
limited to receiving and sending one letter a month. ${ }^{12}$ Needless to say it must have been completely impossible to uphold a meaningful relationship with one's children, family, and friends under such conditions.

During the 20th century the isolation regimes changed gradually but many of the European 19th century prisons are in fact still in use today and although refurbished and renovated to a greater or lesser extent their original architectural design and appearance still influence the way deprivation of liberty is practiced. In Denmark, for example, even today, many remand prisons have no facilities for communal activities except for small exercise courtyards. In Norway, Sweden and Denmark between 1/4 and $1 / 3$ of all prisoners are remand prisoners who, especially in Sweden, are often subjected to especially strict regimes involving isolation or outright solitary confinement and very limited access to correspondence and visits, and none or very limited access to the use of the telephone. ${ }^{13}$

It is also interesting that although all Scandinavian countries feature conjugal visits, which allow privacy during visits and physical contact between family members, it seems that this practice was initially introduced primarily to allow intimacy between prisoners and their partners and not in order to help prisoner's children. As explained by Hanne Hamsund, head of the Norwegian NGO for prisoners relatives, Foreningen for Fangers Pårørende (FFP), in her speech commemorating the organisation's 20th anniversary, children were not very welcome in the Norwegian prisons just a few decades ago. According to Hamsund, the Norwegian 1961 prison regulations stated that children aged three to 14 should only be allowed to visit in prison when such visits could be carried out with a view to the best interests of the child. A folder with information to prisoners' relatives explained how this was to be understood when it simply stated that 'children aged 3-14 should normally not be brought on visits'. ${ }^{14}$

\section{A Children of Imprisoned Parents in Scandinavia - How Many?}

Lack of accurate statistics about a stigmatised group is often an indication that the group is of low status and is unlikely to be anyone's priority'.15 It is difficult to say precisely how many children actually experience having a parent in prison. The explanation is simply that this is typically not registered in any official statistic and I have so far failed to find a country which releases yearly updates or any kind of regular official estimate or

12 Peter Scharff Smith, “Degenerate Criminals": Mental Health and Psychiatric Studies of Danish Prisoners in Solitary Confinement, 1870-1920' in (2008) 35 Criminal Justice and Behavior 1050.

13 Regarding the amount of remand prisoners, see data supplied on the ICPS world prison brief <http://www.prisonstudies.org/info/worldbrief/> (17 June 2014).

14 Quoted from talk by Hanne Hamsund in connection with FFP's 20th anniversary conference in Oslo, 13 June 2013.

15 J Matthews, Forgotten Victims: How Prison Affects the Family (Nacro, 1983), quoting Gill Pugh, Sentenced Families - Signs of Change for Children with a Parent in Prison (Ormiston Children and Families Trust, 2004) 15. 
statistic on the number of prisoners' children. This is one way of showing how these children and their problems have, as a rule, been outside of the authorities', and for many years, also the media's, spotlight.

It would, however, not be difficult to produce such statistics. This could be done simply by writing down how many children a prisoner has when he or she arrives in prison. ${ }^{16}$ In many countries, it would furthermore not be difficult to check such information in the official state registries if the legal requirements are in place. In Denmark, for example, a social worker would normally interview an arriving prisoner about a number of personal issues, so the question of children could easily be added to the checklist as a mandatory question. ${ }^{17}$ It is, of course, possible that some prisoners would not reveal this information, for example, because some parents might fear interference from the social authorities. Such information could, however, be verified by checking the official registry. In Norway, the Association for Prisoners' Relatives (FFP) has proposed to the Ministry of Justice that they ensure central registration of the number of prisoner's children, and the Danish Institute for Human Rights has recommended a similar procedure in Denmark. ${ }^{18}$ In Sweden, on the basis of the Children's Ombudsman's proposal in the report, Don't Punish the Child! (Straffa inte Barnet!) from 2004, a procedure has been introduced according to which, prisoners have to be asked a number of questions including: if they have children, whether or not they have parental custody, and if they live together with the children. These questions are to be used internally in the specific institutions and so far no central registration and no statistical material has been produced as a result. ${ }^{19}$

In Norway, the FFP in cooperation with the Norwegian State Statistical Bureau (Statistisk Sentralbyrå), have estimated that there are between 6000 and 9000 children annually in Norway who experience having a parent in prison. ${ }^{20}$ Another Norwegian study estimate that more than half of all prisoners in Norway are parents and have, on average,

16 One would obviously have to define 'parent' in this case - a category which arguably should not only include biological parents but also others with a parental function.

17 This has in fact been done in some Danish prisons already. Information obtained during a meeting at Vestre Prison in Copenhagen 7 October 2013.

18 See Peter Scharff Smith and Janne Jakobsen Når straffen rammer uskyldige. Børn af foengslede i Danmark (Gyldendal, 2010) 27.

19 There seems to be different practices in terms of how comprehensively prisoners are asked and how they are helped. See Smith and Jakobsen, above n 18, 27, 273. See also Straffa inte barnet, report from Children's Ombudsman, BR2004:01 <http://www.barnombudsmannen.se/publikationer/bestall-och-ladda-ner/straffainte-barnet-2004/> (26 November 2012). Internal attempts by the Swedish Prison Service to use this information statistically have been abandoned as it was discovered that the parental status of the prisoners and the number of children they have is sometimes recorded sloppily in the Swedish prisons (information obtained at a meeting with representatives of the Swedish prison service and the NGO 'Bryggan' (22 May 2013) in Stockholm).

See Smith and Jakobsen, above n 18, 28. 
two children each. ${ }^{21}$ In Sweden it was estimated that there were 8000 Swedish children who had a parent in prison in 1997, but the figure is, almost certainly, significantly higher. ${ }^{22} \mathrm{~A}$ more recent estimate can be found on the homepage of the Swedish prison service, which claims that 30,000 children in Sweden have at least one parent either in prison or under penal supervision. ${ }^{23}$ As far as the whole of the EU is concerned, it has been estimated that annually more than 800,000 children experience having an imprisoned parent. ${ }^{24}$

In Denmark, the most reliable estimates stem from research-based on data obtained directly from the imprisoned parents, as well as Danish register data. ${ }^{25}$ In one study, 803 sentenced prisoners and remand prisoners in Danish prisons responded to a detailed questionnaire in which they noted, among other things, whether they had children and how many. According to the survey 402 prisoners - ie 50\% of those participating - had children and they had 909 children in total. ${ }^{26}$ If we, based on these figures, estimate a quotient of how many children an inmate in a Danish prison has on average, we reach the figure of 1.13 children per inmate. This is very close to an English study where the rate was 1.14 children per prisoner. ${ }^{27}$

With a quotient of 1.13 children per prisoner applied to the average occupancy in Danish prisons in 2010, 2011 and 2012, we see that there are constantly around 4500 children in Denmark who are experiencing parental imprisonment. Based on the same quotient and the number of prisoners who passed through the Danish prison system throughout 2010, there were 14,500 children who experienced parental imprisonment at some point in $2010 .^{28}$ Recent information from the Danish prison service (based on register data), however, shows that (only) around one-third of all

21 Lorraine Sherr, Ane-Marthe Solheim Skar, Claudine Clucasa, Stephen von Tetzchnerb and Karsten Hundeide, Evaluering Av Program for Foreldreveiledning Basert På International Child Development Programme. Norsk Sammendrag. Rapport Til Barne, Likestillings - og Inkluderingsdepartementet, June 2011, 16.

22 See Straffa inte Barnet (Don't Punish the Child) report from Children's Ombudsman, BR2004:011 3. Current Swedish estimates used by the NGO 'Bryggan' are much higher (information obtained at a meeting with representatives of the Swedish prison service and the NGO 'Bryggan' (22 May 2013) in Stockholm.

23 <http://www.kriminalvarden.se/sv/Press/Almedalsveckan/Seminarier/Barn-ibrottets-skugga/> (5 September 2013). It is, however, not clear what the basis for this estimate is or how it has been calculated.

24 Estimate by EUROCHIPS. See also Adele D Jones and Agnieszka E WainainaWoźna (eds) Children of Prisoners. Interventions and Mitigations to Strengthen Mental Health (University of Huddersfield, 2013).

25 Linda Kjær Minke, Fængsletsindre Liv, [PhD thesis] (University of Copenhagen, 2010); Rikke Olsen: Invisible Consequences of Punishment: Parental Imprisonment and Child Outcomes, [PhD thesis] (Aarhus University, 2013).

26 Minke, above n 25.

27 See Smith, above n 1, 45.

28 Lise G Hendriksen, Janne Jakobsen and Peter Scharff Smith, Børneansvarlige $i$ Kriminalforsorgen - Fokus på de Indsattes Børn (The Danish Institute for Human Rights, 2012) 11, 121. 
prisoners are biological parents to one or more children (32\% of all remand prisoners and $34 \%$ of all sentenced prisoners). ${ }^{29}$ This indicates that if the quotient of 1.13 children is more or less right, then quite a few of these children are not biological children or they are more than 18 years old.

Recent Danish research based on register data regarding Danish children born during the period from 1980 to 1985 shows that between $6.10 \%$ and $6.82 \%$ of all children born in that period have experienced parental imprisonment. ${ }^{30}$

\section{B Prisoner's Children in Scandinavia - What are their Problems and How are they Treated?}

On a very general note the problems experienced by prisoner's children in Scandinavia seem very similar to those experienced by children of imprisoned parents elsewhere. This is evident from much of the available Scandinavian and international research. A recent EU study comparing children of imprisoned parents in Sweden, Germany, Romania and the United Kingdom generally confirms this. ${ }^{31}$

This is not to say that there are not differences from one jurisdiction to another and between Scandinavia and the rest of Europe and some of these differences - positive as well as negative - will be discussed later in this article. In the following, I will briefly go through the various stages of the justice process and give a few examples of how children of prisoners in Scandinavia can become caught up in this and suffer from what has been termed as an experience of 'secondary prisonisation'. ${ }^{32}$

The process from the arrest of a parent, over imprisonment, to release can be fraught with numerous very specific problems for prisoners' families and for prisoners' children. While some of these issues will play a minor or no role in some cases, they can also individually constitute major issues for prisoners' children. For some children, a difficult, and perhaps expensive, transportation issue to and from prison, or the question of visiting times and visiting conditions, can, as separate issues in themselves, abruptly quell a relationship between a child and a parent for years on end. Furthermore, if children are not told about the arrest of a parent they can sometimes believe that the parent is dead. A Danish boy, Jonas, for example, remembers living with his father and little brother as a 10-year-old. When his father was scheduled to go sailing for two weeks, the children moved in with their cousin. But his father didn't come home after the voyage. For a week, Jonas feared that the ship had sunk and that his father had perished. Then the police phoned and told him that his

29 Susanne Clausen Klientundersøgelsen 2011 (Direktoratet for Kriminalforsorgen, 2013) 75, 124.

30 See Rikke Fuglsang Olsen 'Forældres Fængsling - En Stratificerende Livsbegivenhed?' (June 2014) 1(25) Dansk Sociologi 13. The article is part of Olsen's PhD thesis, above n 25.

31 Jones and Wainaina-Woźna, above n 24.

32 See, eg, Megan Comfort, Doing Time Together. Love and Family in the Shadow of the Prison (Chicago, 2008). 
father was remanded in custody. This was initially a great relief for Jonas, although a long list of other problems now began to appear. It took three months, for example, before the boys were allowed to visit their father. ${ }^{33}$ Such reactions on part of the children illustrate what Danish practitioners and Swedish research has highlighted, namely that prisoner's children can react very similarly to children with a parent who is seriously ill or dies. ${ }^{34}$

On a general note, there are several studies that show how prisoners' children in Scandinavia can react in many different ways and experience several and significant problems as a result. ${ }^{35}$ A Swedish qualitative interview study, for example, showed that the participating children were 'negatively affected emotionally by parental imprisonment' and that they expressed 'feelings of stigma'. ${ }^{36}$ The children described having different problems in particular 'sleeping problems, feelings of depression, general sadness and negative physical sensations'. ${ }^{37}$ In a comparative EU study, sleeping problems and nightmares were reported with a high frequency among prisoner's children in Sweden and in the UK. ${ }^{38}$

The arrest of a parent can itself be a very unpleasant and decidedly traumatic experience for the children who experience it at first hand. This is clearly described, not only by children, but also by police officers. Common arrest experiences for Danish police officers include children crying, children who were afraid or hostile towards the police and children who clung to their mother or father during an arrest. ${ }^{39}$ By interviewing policemen in Denmark, it was confirmed that they could themselves be very aware of, and affected by, situations where children were present and it was confirmed that seeing and dealing with prisoners' children and their emotional and sometimes dramatic reactions (fear, sadness, hostility) was a normal part of field police work..$^{40}$ In a comparative European study, which includes Sweden, it was found that especially older children of imprisoned parents 'frequently missed school, particularly at times close to the arrest of their parent'. ${ }^{41}$

33 The account and quotes are from Marlene Grøftehauge: Fangebørn (Prisoners' Children) (Aarhus 2004) 82ff. It is not apparent from the account who was responsible for the fact that the two boys were only allowed to visit their father after three months.

34 AB Turesson Mor I Fängelse - Mödrar och Barn Berättar: En Analys Av Ungdomars Resiliensprocess (Gothenburg University, 2009) 17; Smith and Jakobsen above $\mathrm{n} 18$.

35 See Smith and Jakobsen, above n 18; Turesson, above n 34; Jones and WainainaWoźna, above n 24.

36 Richard Steinhoff and Anne H Berman, 'Children's Experiences of Having a Parent in Prison - We look at the moon and then we feel close to each other' (2012) Sociologie Si Asistenta Sociala 77.

37 Ibid, 90.

38 Jones and Wainaina-Woźna, above n 24, 63ff.

39 Smith and Jakobsen, above n 18, Ch 6.

40 Ibid.

41 Jones and Wainaina-Woźna, above n 24, 333. 
Remand imprisonment often constitutes an especially challenging and difficult time characterised by stress and uncertainty for prisoners' families and children. Some parents choose to keep the remand imprisonment secret, and lie to their children and some include the children, but try to keep it a family secret. Some families will begin to experience economic difficulties. Many children also experience shame and guilt in connection with the imprisonment of a parent, and some are bullied. In a Swedish study on children of imprisoned mothers, the author concluded that 'shame was the most dominant feeling in the children'. ${ }^{42}$ The children whose mothers had committed crimes for the first time felt most ashamed and especially if the mothers had committed violent crimes. The children handled the shame in two ways: either by being silent about what happened or by becoming attached to friends with similar life situations. ${ }^{43}$

The situation and the surrounding feelings can be especially intense and difficult to handle during the remand phase where the disappearance of the parent will come as a shock to many children and where the remaining parent (if there is one) will often not have sufficient energy to talk about the situation with the individual child. In some countries remand imprisonment is also characterised by a very strict regime in order to protect the on-going police investigation and in Scandinavia and Poland, for example, remand prisoners are often subjected to special restrictions on visits and contact with the outside world, which can become a serious problem for prisoners' children. I will return to this particular issue below.

When a sentence is passed it can be a relief, in so far as the uncertainty comes to an end. However, in many cases this will be sad news for the child, especially if the parent receives a long sentence. A Norwegian boy remembers the time his mother told him about his father's sentence: 'I remember extremely well when dad got his sentence for 13 years'. The boy was on his way to an after school activity:

Then my mother tells me that dad has been sent to prison for 13 years. I began to cry. I remember I ran out of the car and hid myself behind a trash bin. That's when I had really needed someone to talk to. ${ }^{44}$

Other crucial issues concern the choice of prison - both in terms transport, regime, and visiting conditions. Non-custodial sanctions, such as community service or electronic tagging, are being employed in Scandinavia for some offences and can alleviate the situation greatly for a number of prisoners' children.

When a parent's imprisonment commences, it will depend a great deal on the conditions in the individual prison and its location if and how contact between the child and parent will be able to develop. When it comes to visiting conditions and other possibilities for maintaining contact, there are often significant differences in regimes, rules and practices

42 Turesson, above n 34, 249.

43 Ibid.

44 The quote is taken from interviews with Norwegian children of prisoners made in February 2012 by FFP (Foreningen for Fangers Pårørende) - an NGO for prisoners relatives. See ‘Høringsuttalelse Fra en Gruppe Ungdom', FFP, Oslo. 
from one jurisdiction to another and from one prison to another. The staff and prison culture in the individual prison and, of course, especially in the visiting section, can also be very important in this connection. In this sense, bad visiting facilities and friendly staff will be a preferable combination compared to the opposite. Even upholding regular telephone contact can be very difficult during imprisonment and although modern communications technology offers many possibilities, these are typically feared by law makers and prison administrators. Regardless, the experiences of children, prisoners, prison staff, social workers, researchers, psychologists and other experts tell us that it can often be very difficult to uphold meaningful contact between children and their imprisoned parents, and some fail trying. ${ }^{45}$

As mentioned, the Scandinavian prison systems allow conjugal visits, which enable parents and children to hug, talk, read, draw, play board games etc in privacy. On a very general note, closed prisons and remand prisons will primarily allow indoor visits in relatively small rooms, whereas an extensive use of open prisons in the Scandinavian systems often allow for more liberal practices. In Norway and Denmark, around one-third of all prison spaces are open low security spaces, while the ratio is somewhat different in Sweden with less than one-fifth of all prison spaces being open. ${ }^{46}$

Nevertheless, as I will return to below, visiting conditions have been improved and made more child friendly in many prisons during recent years (including in a number of closed prisons and some remand prisons). But the quality of visiting conditions can still vary significantly from one institution to another. According to a recent study, the 'quality of visiting environments' in Swedish prisons varied considerably, and 'some were reported to be comfortable and well equipped, whilst others were poorly maintained and in need of renovation'. ${ }^{47}$ This is certainly also the case in Denmark, where a number of newly renovated visiting facilities have very high standards - and some allow outside activities, even in closed prisons - while the facilities, especially in a number of old remand prisons, are quite bad and not at all child-friendly.

A very special situation can arise if a child is allowed to live inside the prison with a mother or father. In Denmark, for example, there will on an ordinary day be up to five children in the age group of zero to three years living with an imprisoned parent in the Danish prisons (remand, closed and open), while you can also find a few more and older children living with their parents in some of the prison service's halfway houses. ${ }^{48}$ According to the Danish legislation, children may only stay in prison

45 See, for example, Smith and Jakobsen, above n 18.

46 See the Norwegian 'Kriminalomsorgens Årsstatistikk' (2012) 31; The Danish 'Kriminalforsorgens Statistik' (2012) 14; and regarding Sweden, Norway and Denmark, see Susanne Hildebrandt (ed) 'Nordisk Statistik for Kriminalforsorgen i Danmark, Finland, Island, Norge og Sverige 2006-2010' (2012) 54ff.

47 Jones and Wainaina-Woźna above n 24, 362.

48 Smith and Jakobsen, above n 18. 
with their parents if the conditions in the institution are suitable for the children. ${ }^{49}$ In Norway, on the other hand, children are never allowed to live with an imprisoned parent. ${ }^{50}$

If contact is somehow maintained between the imprisoned parents and their children then there will come a time when release from prison can bring a parent back to the community and perhaps the family. This process is, however, fraught with problems and challenges, and success is by no means guaranteed. The families have changed and perhaps the prisoner as well. A significant strength of the Scandinavian systems in this regard is the relatively extensive use of home leave, which allows a lot of prisoners to maintain a much more normal contact with the family and can create a more gradual return to society. During 2012, the Prison and Probation Service in Denmark granted altogether 15,341 home leaves for prisoners to see family members and 16,959 leaves in connection with education or work. The vast majority of such leaves are granted to prisoners in open prisons. ${ }^{51}$

\section{Scandinavian Penal Culture and Prisoners' Children}

Some criminologists have argued that Scandinavia exhibits an exceptionally humane penal culture in terms of both 'low rates of imprisonment and humane prison conditions', which emerges from 'the cultures of equality that existed in these countries [and became] embedded in their social fabrics through the universalism of the Scandinavian welfare state'. ${ }^{52}$ But while the number of prisoners is easy to establish, a thorough comparative empirical study of actual prison conditions and prison practices in Scandinavia and other countries has never been made. ${ }^{53}$ The closest we have in that regard are probably reports from international and regional human rights monitoring mechanisms, which give relatively detailed information (especially the CPT reports) on actual prison conditions in the countries visited, but unfortunately they have generally not been used by criminologists interested in Scandinavian penal practice. ${ }^{54}$

49 'Straffuldbyrdelsesloven' (the Danish Prison law) § 54, 2.

50 See Smith and Jakobsen, above n 18, Ch 15.

51 Kriminalforsorgensstatistik (2012) 27.

52 John Pratt, 'Scandinavian Exceptionalism in an Era of Penal Excess. Part I: The Nature and Roots of Scandinavian Exceptionalism' (2008) 48 British Journal of Criminology 119. See also John Pratt and Anna Eriksson Contrasts in Punishment. An Explanation of Anglophone Excess and Nordic Exceptionalism (Routledge, 2013).

53 John Pratt, a criminologist from New Zealand, has for example made a number of prison visits in Nordic countries, which consisted of guided tours at the hands of the local prison services - a research method which has been termed 'prison tourism'. See Thomas Mathiesen 'Scandinavian Exceptionalism in Penal Matters: Reality or Wishful Thinking?' and also J Pratt and A Eriksson 'In Defence of Scandinavian Exceptionalism', in T Ugelvik and J Dullum (ed) Penal Exceptionalism? Nordic Prison Policy and Practice (Routledge, 2012) 15 and 236 respectively.

54 See <http://www.cpt.coe.int/en/> (14 October 2013). 
When it comes to research specifically on prisoners' children there have also been attempts to explain differences between Scandinavia and the United Kingdom as a product of welfare state practices and the special character of the Scandinavian welfare states. Quantitative studies have, for example, found that parental imprisonment increases the risk for antisocial and criminal behaviour. By comparing Swedish, Dutch and British data it has however been found, that while parental imprisonment appeared as a likely causal factor in England (and not only a risk factor), a similar effect has not been identified in the Swedish and Dutch material (where parents' criminal habits seems to be the explaining factor rather than their imprisonment). ${ }^{55}$ Criminologists have attempted to explain these differences by referring broadly to the expansive welfare states in Sweden and Holland. ${ }^{56}$

Recent Danish research has however put an interesting twist on this particular issue. By analysing large samples of Danish register data and controlling for various background factors it has been found that parental imprisonment is not an independent predictor of children's number of convictions in early adulthood', which supports the results in the Swedish and Dutch case. ${ }^{57}$ But by analysing different types of serious crime it was also found 'that offspring of imprisoned parents are indeed more likely to engage in criminal activities such as crime against property as young adults', which suggest that there are long term causal effects of parental imprisonment also in Denmark. ${ }^{58}$ Similarly, Danish register data has been used to show that parental imprisonment has an impact on social stratification in Denmark by contributing to maintaining (and sometimes exacerbating) inequality as measured by economy and education. The data demonstrates that among the group of imprisoned parents there is a rising over-representation of fathers in the lowest income group and a rising over-representation of parents with the lowest registered level of education. $^{59}$

A significant problem with some of the quantitative studies is that their data sets and statistical analysis include a potentially significant number of children who had no or minimal contact with their parent before the incarceration, as well as children who might benefit from parental

55 Joseph Murray, Parental Imprisonment: Effects on Children's Antisocial Behaviour and Mental Health through the Life-course, $\mathrm{PhD}$ thesis, University of Cambridge (February 2006) 184. See also Sytske Besemer, Victor van der Geest, Joseph Murray, Catrien CJH Bijleveld and David P Farrington 'The Relationship between Parental Imprisonment and Offspring Offending in England and the Netherlands' (2011) 51(2) British Journal of Criminology 413.

56 See, for example, Joseph Murray, David P Farrington, Ivana Sekol and Rikke F Olsen, Effects of Imprisonment on Child Antisocial Behaviour and Mental Health: A Systematic Review (Campbell Systematic Reviews, 2009); Besemer et al, above n 55.

57 Rikke Fuglsang Olsen 'Parental Imprisonment: A Predictor of Danish Children's Criminal Convictions as Young Adults?' (forthcoming) 18.

58 Ibid.

59 Rikke Fuglsang Olsen 'Forældres Fængsling - En Stratificerende Livsbegivenhed?' (2013) (forthcoming) 16, 18, 19. 
imprisonment. There is, however, no reason to believe that a child who does not know his or her biological father will be affected by his imprisonment, and similarly, children with very limited contact should generally not be expected to be severely harmed on that account. This might explain why one does not find that parental imprisonment causes children mental health problems, ${ }^{60}$ while another study, which is based on a selection of children (including children in Sweden) who have meaningful contact with their imprisoned parent, found that 'children with a parent/carer in prison are at significantly greater risk of mental health problems than children in the general population'. ${ }^{61}$

Although it has never been thoroughly empirically tested or shown that Scandinavian welfare state values produce especially humane prisons and better conditions for prisoners children, it is nevertheless an important question to what degree research on children of imprisoned parents and the negative effects they experience translates across countries and jurisdictions. Societies, culture, penal law, prison practices, social security etc are certainly different from State to State and are very likely to have an impact on the degree and kinds of problems experienced by these children. Obviously, the phenomenon of mass imprisonment in the United States, for example, has some very different consequences compared to the way in which relatively low levels of imprisonment influence society in Scandinavian welfare states. ${ }^{62}$ In the following, I will touch upon some of the both positive and negative aspects of Scandinavian practice which affects prisoner's children directly.

\section{A The Case of Remand Imprisonment in Scandinavia}

The use of solitary confinement and other isolation like regimes during pre-trial detention has been practised extensively in Norway, Denmark and Sweden for many years. ${ }^{63}$ The official reason is typically that very strict regimes are needed to avoid collusion, that is, the suspect interfering

60 Joseph Murray, David P Farrington and Ivana Sekol 'Children's Antisocial Behavior, Mental Health, Drug Use, and Educational Performance After Parental Incarceration: A Systematic Review and Meta-Analysis' (2012) 138(2) Psychological Bulletin 190.

61 Jones and Wainaina-Woźna above n 24, 292.

62 This has not been adequately explained nor researched so far. For some of the existing discussions on this see, eg, S Besemer, V Vander Geest, Joseph Murray, Catrien CJH Bijleveld and David P Farrington, 'The Relationship between Parental Imprisonment and Offspring Offending in England and the Netherlands' (2011) 51(2) British Journal of Criminology 413-437. On the other hand, the (alleged) positive aspects of penal practice in the Scandinavian welfare states are sometimes taken for granted and the less positive sides overlooked. See, eg, Peter Scharff Smith 'A Critical Look at Scandinavian Exceptionalism: Welfare State Theories, Penal Populism and Prison Conditions in Denmark and Scandinavia' in T Ugelvik and J Dullum (ed) Penal Exceptionalism? Nordic Prison Policy and Practice (Routledge, 2012) 38-57.

63 Regarding this practice in Norway, a thorough $\mathrm{PhD}$ study is underway, authored by Thomas Horn, Oslo University. 
with the investigation. Since the late 70 s, this practice has been widely criticised within Denmark, and especially since the 90s, international criticism has been directed at Norway, Sweden and Denmark. This criticism has been voiced not least by the torture prevention committees of the United Nations and the Council of Europe and this practice has been termed a 'peculiarly Scandinavian phenomenon'. ${ }^{64}$ Such international criticism is, however, in stark contrast to the traditional view of a humanistic Scandinavian liberal approach to punishment.

The fundamental problem is, that when you put people into solitary confinement under conditions where, typically, they remain in their cells for about 22-24 hours every day and have minimal access to psychological, meaningful social contact, they are exposed to a number of potentially very negative effects. The effects of solitary confinement have been the object of numerous studies internationally and in Denmark, which clearly show that a significant number of prisoners in solitary confinement will experience negative health effects. ${ }^{65}$ Among the possible negative effects are, for example, anxiety and depression, but solitary confinement can also cause a number of other psychological and physiological problems and, in some cases, insanity. ${ }^{66}$ Interestingly, a Swedish psychiatric study of remand prisoners in solitary confinement showed that remand prisoners with children were at greater risk of suffering negative health effects while imprisoned, compared to remand prisoners without children. ${ }^{67}$ This is likely caused by imprisoned parents experiencing a greater loss through their confinement because they are removed and isolated from their children.

The European Commission for the Prevention of Torture (CPT), which periodically inspects prisons in the member states of the Council of Europe, has reported in detail on the problems of solitary confinement based on their visits in Norway, Sweden and Denmark between the years 1990 and 2012. They have visited Denmark four times, and Norway and Sweden five times. All visits to date have given rise to criticism about the use of solitary confinement of detainees (in Norway and Sweden, solitary confinement is used under the heading 'restrictions'). ${ }^{68}$ If we look at the most recent visits (Norway 2011, Denmark 2014, and Sweden 2009) criticism has continued, although improvements in especially Denmark and

$64 \quad$ Malcolm Evans and Rod Morgan, Preventing Torture. A Study of the European Convention for the Prevention of Torture and Inhuman or Degrading Treatment or Punishment (Clarendon Press, 1998). The authors characterise pre-trial solitary confinement as a 'peculiarly Scandinavian phenomenon' 247.

65 See, Smith, above n 11, 503. See also, Peter Scharff Smith 'The Effects of Solitary Confinement. Commentary on One Year Longitudinal Study of the Psychological Effects of Administrative Segregation' in Corrections and Mental Health (National Institute of Corrections, 2011).

66 For a summary of the many possible negative effects, see Smith above n 11.

67 Bengt Holmgren, Thomas Frisell and Bo Runeson, Psykisk Hälsa Hos Häktade Med Restriktioner, (Kriminalvårdens Utvecklingsenhet, 2011) 1-40.

68 See eg, CPT, Visit Report, Denmark, (1990) s 13/65; CPT, Visit Report, Sweden, (1991) s 26/58; CPT, Visit Report, Norway, (1993) s 22/45. 
Norway were also appreciated. The CPT delegation noted fewer positive developments in Sweden in 2009 and commented that although:

Efforts were being made at Gothenburg Remand Prison to partially or totally lift restrictions after a period of two to three months ... a substantial proportion of remand prisoners at Gothenburg had restrictions, some being subjected to long periods of isolation (from 6 to 18 months) ... The delegation gathered direct evidence - supported by the observations of health-care staff - of the damaging effects of isolation due to restrictions imposed on inmates. ${ }^{69}$

A report from the prosecutions office has shown that in 2013 around two-thirds of all remand prisoners were in fact placed in isolation. ${ }^{70} \mathrm{It}$ has recently also been documented that Swedish authorities have shown a remarkable lack of concern for children's rights and wellbeing when arresting and detaining juveniles between 15 and 17 years old. These juveniles are routinely subjected to solitary confinement and sometimes not allowed to contact their parents for over a month. ${ }^{71}$

The use of pre-trial solitary confinement has dropped very significantly in Denmark during recent years. What is less known is the fact that a normal day for many remand prisoners who are officially not in solitary confinement is nevertheless spent in isolation-like regimes with around 22-23 hours in cell time. A very large proportion of remand prisoners are also subjected to an extra tight control regime including supervised visits.

\section{B Remand Regimes and Prisoner's Children}

The conditions of prisoners during remand imprisonment are in many ways based on the assumption that remand in custody should be for a short period only. But in practice this is far from always the case. In Denmark, the use of remand imprisonment has risen significantly during recent years. A full one-third of all prisoners in Denmark are currently remand prisoners and the use of 'long-term remand', which last for more than three months, has gone up $45 \%$ from 2007 to $2010 .^{72}$ The specific problems related to remand imprisonment therefore affect a growing number of prisoners' children in Denmark.

When applied in connection with remand imprisonment, solitary confinement and other isolation like regimes occur very suddenly - the person is arrested (on the street, in the home etc) and then placed directly in isolation. For the children this basically means two things: the parent is suddenly extremely restricted in his or her connection with family; and

69 CPT visit to Sweden 2009, preliminary observations. Available at: <http://www. cpt.coe.int/en/states/swe.htm> (accessed 7 October 2014).

70 Åklagarmyndigheten 'Häktningstider och restriktioner', report January 2014.

71 Barnombudsmannen, Från Insidan. Barn och Ungdomar Om Tillvaron I Arrest och Häkt' (Barnombudsmannen, 2013).

72 See report from the Danish Ministry of Justice <http://www.justitsministeriet. $\mathrm{dk} /$ sites/default/files/media/Arbejdsomraader/Forskning/Forskningsrapporter/ Varetaegtsfaengslinger_2010.pdf> (16 March 2013). 
the parent can be harmed by the isolation which of course can have a profound effect on the children.

Solitary confinement of a remand prisoner and isolation like regimes can have the consequence that the contact between the child or children and the parent stops entirely for long periods. However, police officers state that it is normal practice to grant permission for solitary confined prisoners to have visits by their children. ${ }^{73}$ It is nevertheless obvious that if the parent suffer negative health effects it can impact the parent role and perhaps also result in the lack of will or ability to meet with the children. Furthermore, visits during remand imprisonment are often supervised by a police officer, which can create a very strange situation for the children, as I will return to below.

Several of the prisoners in a Danish study had experienced being in solitary confinement in connection with remand imprisonment. ${ }^{74}$ The majority had experienced it as an intense strain and some described the way it affected their contact with their children:

I was in solitary confinement for 7 months and only saw my children after 6 months. For the first 4 months I had a visiting ban ... I thought that was unreasonable. I felt really bad about that.

In the long term, solitary confinement and lack of contact can result in, among other things, that young children reject the parent at a later stage. ${ }^{75}$ How this can happen is illustrated by a mother who experienced being arrested (while her husband was arrested), put into solitary confinement and later released:

They arrived with police cars and took me into prison ... I was told that the children were at an institution. They said they could detain me as long as necessary. I was in solitary confinement for one month, then yet another month where I was allowed visits, but just not from my husband ... Then I was told that I was released and that the children would come home ... The youngest, who was 2-years old at the time, didn't want anything to do with me. In two months he had forgotten me. That felt very cold. He wouldn't come to me. He went to others when he had to go to the toilet or eat. A week went by where he didn't want anything to do with me and only after 1-2 months, would he have contact with me ... When we came home, everything looked like I don't know what. No one had been here since I was arrested ... The flowers had died and everything was just a mess, they had ransacked everything, of course ... I just broke down. I couldn't cope with anything. For six months I think, I just sat and cried. Finally, my children said to me that enough was enough; now I had to do something ... But I still cry over the smallest thing. ${ }^{76}$

73 Bent Volf, criminal police superintendent in 2006 and employed in South and Southern Jutland Police in 2010 (Telephone interview June 2006 and January 2010); Steffen Steffensen, detective inspector at Copenhagen Police (Telephone interview June 2006 and January 2010). None of them could come up with instances where visiting permission has been rejected for children of solitary confined remand prisoners. See Smith and Jakobsen, above n 18.

74 Else Christensen, Forcldre I Foengsel (SFI, 1999) 44.

75 Ibid, 45 .

76 Ibid, 45 . 
A particularly intense security control arises in the situation where a remand prisoner only has permission for supervised visits. If the remand prisoner is subjected to correspondence and visiting control, then the police are present during the visit in order to ensure that the case is not spoken about. The police officer who supervises the visit can either be the officer who works on the case, a member of a special visiting unit, or a 'random' officer who is ordered to supervise visits on the day concerned.

Having access to only a one hour or half an hour visit each week and with a police officer present can be a very stressful experience and extremely awkward and problematic for visiting children. Unfortunately, there are no official Danish statistics on how often these restrictions are imposed on prisoners, but a count made on the 27 May 2013 showed that $70.4 \%$ of all remand prisoners in the entire Danish prison system at that time were subjected to correspondence and visit control. ${ }^{77}$ In addition, being subjected to supervised visits often means that visits are only allowed on weekdays in the period from around 10am until approximately $2 \mathrm{pm}$ because police officers have to be available. In reality, this can easily make regular visits impossible because children are in school and partners often work.

A family therapist in the Danish prison service describes how children tell her that it is 'unpleasant that someone is sitting there and listening to their conversation' during supervised visits. ${ }^{78}$ Kristian, whose father is in prison, explains:

The first prison he, [father] was in, it was just like ARGH! An officer had to stand there and hear what we talked about. We sat in such a small room and it felt as if you were completely surrounded by people you didn't know. ${ }^{79}$

When it comes to the use of telephone then remand prisoners in Denmark are normally not allowed to use the phone at all. This means that you can be imprisoned on remand for months up to more than a year without ever being allowed to call your children. In a Danish study, prisoners explained that the limited telephone access was particular distressing with regard to keeping contact with the children. The prisoners thus preferred to talk on the telephone instead of writing letters. For some, it was about their children being young and unable to read. A prisoner also explains that he has never been good at writing. ${ }^{80}$ That the telephone was simply not accessible during remand imprisonment was therefore a big problem. The prisoner explained that it would have taken a great deal of pressure off the children if it had been possible to call home and say goodnight. ${ }^{81}$ Similarly, many children find letter writing an awkward way of communicating: 'Many children see writing as a chore, an extension of homework, and

$77 \quad$ Figures emailed from the Danish Prison and Probation Service to the Danish Institute for Human Rights on (21 June 2013).

78 Rikke Betak, family therapist in the Family House in Halfway House Engelsborg.

79 Kristian whose father is in prison. Kristian is not the boy's real name. See Smith and Jakobsen, above $\mathrm{n} 18$.

80 Christensen, above n 73, 49.

81 Ibid, 46. 
far from a fun activity'. ${ }^{82}$ In Sweden, the problem in this regard seems to be very similar when it comes to remand prisoners and telephone access. According to a study, parents in remand prisons in Sweden are permitted 'few, if any, telephone calls' by the prison. ${ }^{83}$

Keeping in mind that most children today communicate a great deal via the mobile phone and text messaging, it would be appropriate if possibilities could be established for prisoner's children to communicate with their imprisoned parent via mobile phone. As described by the Head of the Prison and Probation Service's Sentence Enforcement office in Denmark: 'surveys show that Denmark is one of the countries in which text messaging is very popular. That arguably tell us that is has become a very, very integrated part of our society over time'. She highlights security concerns and economical concerns as the main reason that access to mobile phones is not more common. ${ }^{84}$

\section{Good Practice-Children's Officers, Visiting Conditions and Children's Rights}

While especially remand prison practice can become a huge challenge for prisoner's children in Scandinavia, there is no doubt that very significant reforms and positive changes have also taken place during the last decade. Reforms have, to a greater or lesser extent, been fuelled by cooperation between prison services, prisoner relatives NGOs, children's ombudsmen and children's rights NGOs as well as researchers in the area. The reform processes have been initiated on a national level but now such a cooperation also exist on a Scandinavian level, where three meetings have taken place in Denmark 2011, in Norway 2012, and in Sweden in 2014, with the prison services, the Children's Ombudsmen and relevant NGOs and researchers attending. A fourth meeting is to take place in Sweden in 2015.

Children's rights have also played a significant role in the reforms in Sweden, Norway and Denmark, where the Children's Ombudsmen (in Norway and Sweden) and The Children's Council and the Danish Institute for Human Rights (in Denmark) have adopted this perspective on prisoners' children and argued how children's rights should be interpreted in that particular context. ${ }^{85}$ Reforms and initiatives within the Scandinavian prisons have also been described by the prison services themselves as being motivated and understood within a children's rights context. So far,

$82 \quad$ C Mazza 'And then the World Fell Apart: The Children of Incarcerated Fathers' in Families in Society: (2000) 83(5) The Journal of Contemporary Social Services 524 .

83 Jones and Wainaina-Woźna, above n 24, 365.

84 Ina Eliasen, Office Manager, Sentence Enforcement Office, The Directorate of the Prison and Probation Service.

85 Concerning Sweden, see for example, Straffa inte Barnet (Don't Punish the Child) report from Children's Ombudsman, BR2004:01; in regard to Norway, see for example <http://www.barneombudet.no/fengsletfamilie/>; and concerning Denmark, see, eg, Smith and Jakobsen, above n 18. 
Norway has taken the lead in this regard by writing the rights of the child directly into the national prison law. ${ }^{86}$ As a general principle, Norwegian prison law thus stipulates that 'children's right to contact with their parents shall receive special attention' during the implementation of the imprisonment. ${ }^{87}$ This could be termed a (children's) rights-based approach to prison management, at least in principle - of course, concrete standards and child-friendly practices have to follow for this to be a reality.

An important concrete focus area in the Scandinavian reform processes has been visiting conditions in prisons and, during the last decade, many visiting rooms and visiting areas have been improved and made more child-friendly in Scandinavian prisons - although conditions as previously mentioned still vary significantly from one institution to another. A number of prisons now also have facilities for overnight visits for families with children, and most of these have been introduced during the last five or ten years. Many of the new facilities are very welcoming and live up to the principle of normalisation also when viewed from the children's perspective. ${ }^{88}$

In Sweden, Norway and Denmark parental study groups and/or parental programmes have also been employed in order to improve the situation for prisoner's children. In Sweden the use of parental study circles has been evaluated positively and in Norway the parents in prison participating in a parental guidance programme showed increasing emotional involvement in their children. ${ }^{89}$ In Denmark study groups and parenting programmes have been attempted in different ways and are currently employed as part of the Children's Officer programme, and in Vestre prison, the biggest remand prison in Denmark, as part of a newly developed programme Dad Behind Bars (Far Bag Tremmer).

A major vehicle for the child friendly improvements has been - and still is - the institution of Children's Officers, which was initially established in Sweden in 2005, has now also been rolled out in Denmark (from 2013 to 2014), and is currently being implemented in Norway. Children's Officers are prison staff (typically prison officers or social workers), who are responsible for anchoring a children's rights perspective in their institutions with regard to prisoners' children. This entails working with visiting conditions, visiting procedures, parental study circles, special child centred events in the prison and many other things.

86 Norway has also incorporated the UN Convention on the Rights of the Child into national law, which is not the case in Sweden and Denmark. It is currently under consideration to do so in Denmark and a committee is discussing incorporation of the CRC and other human rights conventions.

87 Lov Om Gjennomføring av Straff Mv (lov-2001-05-18-21) § 3. See also Hans Jørgen Engbo and Peter Scharff Smith, Fongsler og Menneskerettigheder (Jurist og Økonomforbundets Forlag, 2012) 273.

88 See Hendriksen, Jakobsen and Smith, above n 28.

89 The Norwegian programme is based on ICDP (International Child Development Programme). See L Sherr, AMS Skar, C Clucas, S von Tetzchner and K Hundeide, Evaluation of the Parental guidance program. Report to the Ministry of Children, Equality, and Social Inclusion (2011) 25. 
In Norway, a bill has been dicussed, which will propose a framework for children's officers in Norwegian prisons as well as a number of other initiatives aimed at improving conditions for prisoners' children. These might include registration of whether prisoners have children as well as rules and guidelines for when the issue of prisoner's children should otherwise be taken into account during imprisonment of a parent..$^{90}$

In Denmark, a trial project with Children's Officers was initiated by my colleague Janne Jakobsen and myself (later managed by our colleague Lise Garkier Hendriksen) carried out together with the Danish Prison and Probation Service. ${ }^{91}$ The project ran for two years, 2010-2011, in two remand prisons, one open prison, and one closed prison and focused on introducing simple and reliable measures to improve children's contact with their parents as well as their experience when visiting in prison. Activities conducted by the Children's Officers included improvement of visiting facilities and visiting procedures, arranging child-friendly events, introducing different measures to help imprisoned parents deal with parenthood (parenting study groups, individual talks, running 'bedtime stories' projects etc) and disseminating information to colleagues on how to welcome and handle children visiting the institution. Afterwards, when the project was finalised and the funding had been spent, the Danish Prison and Probation Service continued the activities in the four institutions and, in November 2012, the Danish government and parliament decided to implement the Children's Officers scheme on a national basis. All Danish prisons (remand and for sentenced prisoners) have therefore had Children's Officers since 2014. ${ }^{92}$

The institution of Children's Officers can be very valuable - when implemented systematically and with sufficient support from management - in terms of both raising awareness about prisoners children in the prisons involved and by creating concrete and important changes in visiting conditions, programme activities etc, which is very likely to have an impact on a significant number of children. The institution of Children's Officers is also a very interesting way of working with - and perhaps reforming - elements of prison culture. The Children's Officers put an amazing amount of time, energy and purpose into their work - sometimes while facing serious scepticism or criticism from colleagues. Their general feeling was clearly that it paid off. As explained by an imprisoned dad who participated in a parental study group run by two of the Danish Children's officers: 'I have changed my whole way of interacting with my wife and kids. The visits have improved, when my family have been here

90 Personal email correspondence with Hanne Hamsund, FFP, Norway, 25 October 2013; Meeting with the Norwegian Ministry of Justice, 21 March 2013.

91 The funding came from Ole Kirks Foundation, which belongs to the toy manufacturer LEGO.

92 See 'Aftale Om Kriminalforsorgens Økonomi I 2013-2016'. Available in Danish at: <http://www.justitsministeriet.dk/sites/default/files/media/Pressemeddelelser/ pdf/2012/Aftaletekst-KRF.pdf> (22 November 2012). 
[in the prison]'. ${ }^{93}$ In that sense, the Children's Officers project constitutes an effort in a broader sense towards lessening the barriers between both prison officers and prisoners, as well as between prisons and the surrounding society - through focusing on the plight of prisoners children.

\section{Conclusion}

I could never get hold of him. He was always the one who had to get hold of me, once every week [on the phone]. Well, that is no father role. There is no one you can go to. It's someone you have to wait to come to you. I don't think that's a father. ${ }^{94}$

The use of imprisonment carries with it a long list of challenges and serious problems, which reach far beyond the question of how the individual prisoner react to being deprived of liberty. Putting people away in prisons can, for example, have a direct and major influence on the lives of prisoner's relatives and by looking specifically at prisoners children we can begin to understand some of the serious impact and intergenerational effects that the use of imprisonment has on our societies.

The situation of prisoners' children in Scandinavia is, in many ways, similar to that of prisoners' children in many other countries. Research show that parental imprisonment can have very serious consequences for the involved children, if those children have a close and meaningful contact to the parent in question. There are numerous ways in which prisoners' children can experience negative effects throughout the justice process and many of these problems resemble what has been reported in non-Scandinavian research.

A particularly problematic Scandinavian issue is that of very strict remand regimes and sometimes long periods of remand imprisonment, with high levels of isolation and no, or very limited, access to telephone calls. There are, however, several positive aspects of Scandinavian practice in this area as well: on a general note, the relatively low levels of imprisonment, the extensive use of open prison regimes (especially in Norway and Denmark), the use of home leave and the use of alternatives to imprisonment, such as electronic tagging. A particularly important Scandinavian development in this area is the increasing focus on children's rights and the evolving Children's Officers model. The developing role of children's rights is interesting in several ways, since, traditionally, discussions, research, court judgments etc within the field of prisons and human rights have almost exclusively been a matter of balancing the state's legitimate use of power and security concerns against the individual prisoners' rights. The question of whether, how, and to what degree the use of imprisonment has also affected the rights of persons outside of prison has, however, for many years, been left out of consideration. But there are currently signs that this might be changing, and some of the

93 Quoted from Hendriksen, Jakobsen and Smith, above n 28, 75.

94 Information provided by Anne in an interview on <http://www.elbecks.dk/ minfarifaengsel/>. 
child-friendly reforms in the Scandinavian prisons systems are arguably an example of this.

But there is still a long way towards making sure that children's rights are always taken into account. In other words, we need to make sure that children's rights, when applied to prisoners' children, are not just abstract principles, but actual legal rights with practical implications. Such a process should produce concrete national standards with regards to numerous issues like the child-friendly quality of visiting conditions and visiting practices, as well as basic issues concerning a child's right to visit his or her parent. What, for example, does the child's right to maintain contact with a parent actually mean? How much time can be allowed to pass before a first visit is established? How often does a child actually have the right to visit a parent and for how long? The latter is an important issue indeed and it would be very useful to start setting concrete standards in such an area in order to meaningfully interpret and flesh out the child's right to maintain contact with his or her parents.

As shown, an important step towards recognising the rights of prisoners' children in national law has been taken in Norway and Norwegian prison law has now established children's right to contact with their parents as a general principle and requirement that 'shall receive special attention' during the imprisonment. ${ }^{95}$ But there is arguably still a long way to go in terms of actually securing the rights of prisoners' children through concrete standards.

The very basic challenge is that we need to reform our systems of justice and punishment in order to take the innocent children of offenders and their needs, situation and rights into account. Although we have had prisons and prisoners' children for centuries, this is still a daunting challenge, considering the way, and the extent to which, imprisonment is used and practised in most nations today.

$95 \quad$ Lov Om Gjennomføring Av Straff Mv (lov-2001-05-18-21) § 3. See also Engbo and Smith above n 86, 273. 